\title{
Wybrane rzadkie przyczyny udaru mózgu u dzieci i młodziėy
}

\section{Selected rare causes of stroke in children and adolescents}

\author{
Ewa Pilarska* (D), llona Kopyta** (iD) \\ *Klinika Neurologii Rozwojowej, Katedra Neurologii, Gdański Uniwersytet Medyczny \\ ** Katedra i Klinika Neurologii Dziecięcej, Wydział Nauk Medycznych w Katowicach \\ DOI:10.20966/chn.2020.58.460
}

\section{STRESZCZENIE}

Udar mózgu (ang. AlS, arterial ischemic stroke) w populacji dzieci i młodzieży występuje z częstością około 3 nowych zachorowań na 100000 dzieci w ciągu roku; częściej pojawia sie w okresie noworodkowym, a kolejno- w wieku adolescencji. Czynniki predysponujące do wystąpienia udaru dziecięcego są inne niż w populacji pacjentów dorosłych, a jednocześnie bardzo złożone. Aktualnie wśród najistotniejszych czynników ryzyka AIS u dzieci, z uwagi na częstość występowania, wyróżnia się arteriopatie naczyń mózgowych, wrodzone i nabyte choroby serca oraz stany sprzyjające zakrzepicy. Obraz kliniczny zależy od lokalizacji ogniska udarowego, a także od wieku pacjenta. Większość udarów dziecięcych lokalizuje się w zakresie przedniego kręgu unaczynienia mózgowia, wobec czego w obrazie klinicznym ostrej fazy choroby dominują porażenia i niedowłady kończyn oraz nerwów czaszkowych, a także afazja. U noworodków i niemowląt objawy często są niespecyficzne. Większość dzieci po przebyciu udaru mózgu prezentuje trwałe następstwa, zwłaszcza niedowłady, zaburzenia mowy o typie afazji oraz padaczkę pourazowa. W diagnostyce różnicowej ostrego niedokrwienia mózgu u dzieci należy jednak uwzględnić także przyczyny rzadko występujące, zwłaszcza, jeśli ich rozpoznanie daje możliwość leczenia i uniknięcia nawrotów udaru. Autorki przedstawiają opis wybranych rzadkich schorzeń, w przebiegu których występują udary niedokrwienne mózgu w populacji pediatrycznej.

Słowa kluczowe: udar mózgu, etiologia, czynniki ryzyka, choroby rzadkie, dzieci, młodzież
ABSTRACT

Arterial ischemic stroke (AIS) in the population of children and adolescents occurs with the frequency of about 3 new cases per 100,000 children per year; it appears more often in the neonatal period, and then - in adolescence. The factors that predispose to childhood stroke are different from that of the adult population, yet very complex. Currently, the most important risk factors for AIS, due to their frequency, include arteriopathies of cerebral vessels, congenital and acquired heart diseases and thrombophilia. The clinical presentation of stroke in children depends on the location and size of ischemic focus as well as on the age of patient. Most cases of pediatric stroke come from the anterior part of brain arterial vasculature so clinical symptoms at stroke onset are paresis or paralysis of extremities and cranial nerves and aphasia. In newborns and infants the stroke symptoms are non-specific. Most children who underwent ischemic stroke present persistent outcomes, most commonly- hemiparesis, aphasia and post-stroke epilepsy. In the differential diagnosis of acute cerebral ischemia in children, however, rare causes should also be considered, especially if their diagnosis enables treatment and avoiding recurrence of stroke. The authors present selected rare diseases in the course of which ischemic strokes occur in the pediatric population. Key words: stroke, etiology, risk factors, rare diseases, children, adolescents

\section{WSTĘP}

Częstość występowania udaru niedokrwiennego mózgu u dzieci według różnych badaczy szacowana jest na 1.2 do 7.9 na 100000 populacji dziecięcej w ciągu roku i zależy od regionu geograficznego, wieku pacjentów rekrutowanych do badania, a prawdopodobnie częstość pozostaje niedoszacowana. Być może wynika to stąd, że niektóre $\mathrm{z}$ nich są bardzo rzadko obserwowane u dzieci, a ich diagnostyka jest bardzo trudna.

Ze względu na etiologię rzadkie przyczyny udaru niedokrwiennego u dzieci młodzieży można podzielić kilka grup:

1.Zapalenia naczyń: choroba Takayashu, guzkowe zapalenie tętnic, toczeń układowy trzewny, reumatoidalne zapalenia stawów, dysplazja włóknisto-mięśniowa, CADASIL, choroba Kawasaki.
2. Zespoły nadkrzepliwości: zespół antyfosfolipidowy, niedobór białka $\mathrm{C}$, niedobór białka $\mathrm{B}$, niedobór antytrombiny III, DIC

3. Choroby hematologiczne: czerwienica prawdziwa, anemia sierpowatokrwinkowa, zespól hemolityczno- mocznicowy.

4. Zespoły uwarunkowane genetycznie: CADASIL, MELAS, homocystynuria, choroba Fabry'ego [1].

W niniejszej artykule omówione zostaną wybrane, najrzadziej spotykane przyczyny, o których należy pamiętać, poszukując potencjalnych czynników ryzyka udaru zwłaszcza u młodzieży.

Zapalenia naczyń mózgowych przyczyniające się do wystąpienia udaru niedokrwiennego wg niektórych autorów (Balabanov, Dore-Duffy), można podzielić się na pierwotne i wtórne [2]. 
Pierwotne to układowe do których zalicza się: chorobę Takayashu, guzkowe zapalenie tętnic, chorobę Kawasaki, ziarniniakowatość Wegnera, plamica Schonleina- Henocha. Nieukładowe to: nieukładowe zapalenie naczyń z neuropatią.

Jedną z częstszych przyczyn udaru mózgu w populacji dziecięcej jest pierwotne zapalenie naczyń ośrodkowego układu nerwowego, którego rozpoznanie jest trudne szczególnie na niespecyficzne wyniki badań laboratoryjnych i neuroobrazowych.

\section{ZESPÓt EHLERSA- DANLOSA (ANG. EHLERS-DANLOS SYNDROME, EDS)}

Zespół Ehlersa- Danlosa charakteryzuje się nadmierną elastycznością skóry oraz stawów a także z często współistniejącym utrudnionym gojeniem ran. Podłożem stwierdzanych zaburzeń są nieprawidłowości w syntezie kolagenu. Szacuje się, że na zespół Ehlersa-Danlosa choruje 1:2500 - 1:10 000 osób. Rozbieżność wynika prawdopodobnie z rzadkiego diagnozowania choroby. Skrót EDS pochodzi od nazwisk Edvarda Lauritza Ehlersa ( duńskiego dermatologa) oraz Henri'ego- Aleksandre'a Danlosa (francuskiego lekarza) [3].

Aktualnie wyróżnia się 14 typów EDS, z czego tylko typ hipermobilny (V) nie ma jeszcze określonej mutacji genetycznej.

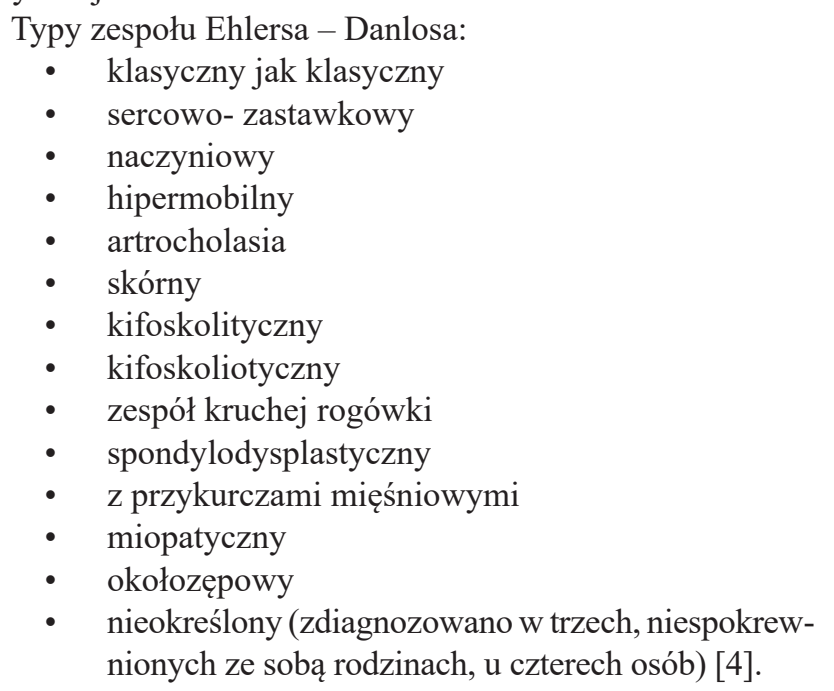

W większości przypadków choroba dziedziczy się autosomalnie dominująco, rzadziej recesywnie, czasami pojawia się mutacja de novo. Postać naczyniowa zespołu zaliczana do typu IV dziedziczy się w sposób autosomalnie dominujący i związana jest $\mathrm{z}$ mutacją $\mathrm{w}$ genie COL3A na chromosomie 2 q32 odpowiedzialnym za syntezę kolagenu typu III. Cechą charakterystyczną tego typu są nieprawidłowości w budowie naczyń, prowadzące do powstawania tętniaków tętnic mózgowych, które mogą powodować pękanie lub rozwarstwienie [5]. Postać ta stanowi jedną z częstszych przyczyn krwotoków śródmózgowych również u dzieci. Do podstawowych objawów zespołu zalicza się nieprawidłowości stawowe oraz skórne. Stwierdza się niestabilność/ wiotkość stawów, co prowadzi do ich dyslokacji, podwichnięć i licznych urazów. Skóra jest delikatna, jedwabista, zwykle rozciągliwa, trudno gojąca się po urazach co sprzyja powstawaniu bliznowców. U części pacjentów stwierdza się wadę serca, najczęściej niedomykalność zastawki mitralnej serca, wady wzroku ((astygmatyzm), odklejenie siatkówki, zmienność wad wzroku i trudności w doborze prawidłowych okularów, sztywność, koślawość lub szpotawość stóp i lub kolan a także wady kręgosłup (skolioza, lordoza) [6]. Obecnie prowadzone są prace nad terapiami genetycznymi z zastosowaniem komórek macierzystych.

Zespól MELAS, encefalopatia mitochondrialna z kwasicą mleczanową i udarami (ang. Mitochondria Encephalopathy with Lactic Acidosis and Stroke- like Episodes) jest schorzeniem spowodowanym mutacją mitochondrialnego DNA. Częstość jego występowania szacuje się na 60:100 000 .

Chorobę dziedziczy się jedynie po linii matczynej, przy czym mutację w obrębie mitochondrialnego genu MTTL1 kodującego tRNA dla leucyny: $3243 \mathrm{~A}>\mathrm{G}$ potwierdzono u około $80 \%$ pacjentów[7]. Zaburzenia są najbardziej widoczne w tkankach, które potrzebują dużych ilości energii do prawidłowego wykonywania swoich zadań (nerwowa oraz mięśniowa), co powoduje szereg objawów. Pierwsze objawy pojawiają się w $75 \% \mathrm{w}$ dzieciństwie między 3 a 15 r.ż., choć opisano pierwsze oznaki choroby także u osób dorosłych. Nasilenie objawów i ich różnorodność są zmienne. W dzieciństwie objawy są mało charakterystyczne, m.in. męczliwość i bóle mięśni, nietolerancja wysiłku. Mogą wystąpić bóle głowy migrenowe. Opisano przypadki w których pierwszymi objawami były drgawki z połowiczym niedowładem. Inne objawy, mniej specyficzne dla choroby MELAS, które mogą się również pojawić w jej przebiegu, to: niedoczynność przytarczyc, cukrzyca, uszkodzenie nerek, głuchota, niski wzrost, zaparcia oraz uszkodzenie mięśnia sercowego, zaburzenia widzenia i ślepota korowa.

$\mathrm{W}$ diagnostyce zespołu poza badaniem neuroobrazowym pomocne są:

- Spektroskopia rezonansu magnetycznego, która wykazuje obecność kwasicy moczanowej w mózgu.

- $\quad$ Oznaczenie stężenia kwasu mlekowego w surowicy po wysiłku fizycznym oraz podwyższenie jego poziomu w płynie mózgowo- rdzeniowym.

- Biopsja mięśnia szkieletowego, w którym stwierdza się obecność charakterystycznych postrzępionych (szmatowatych) włókien (ang. Ragged Red Fibres-RRF) [8].

Zmiany w narządzie wzroku mogą być wielorakie i stwierdzane już u dzieci [9]. Mogą obejmować retinopatię barwnikową, oftalmoplegię zewnętrzną, opadnięcie powieki, zaćmę podtorebkową tylną oraz atrofię nerwu wzrokowego.

Mogą występować napady padaczkowe ogniskowe lub uogólnione toniczno- kloniczne. Z innych objawów neurologicznych obserwuje się ataksję, dystonię, drżenia.

W przebiegu choroby pod wpływem różnych czynników m.in. infekcji, nadmiernego podaży węglowodanów, dochodzi do powiększenia się komórek śródbłonków naczyń krwionośnych co prowadzi do zaburzeń przepływu mózgowego i wystąpienia udarów mózgu. 
Zawały lokalizują się zwykle w tylnej części płata skroniowego, płatach ciemieniowym oraz potylicznym. Zwykle udary mózgu występują późno, w trzeciej lub czwartej dekadzie życia. W piśmiennictwie istnieją opisy rozpoznania zespołu MELAS u dzieci ze zmianami w rezonansie magnetycznym w postaci hiperintensywnych obszarów w płatach skroniowych i potylicznych [7].

Nie opracowano dotychczas leczenia zespołu MELAS. Możliwe jest leczenie objawowe. Stosowane są terapie z zastosowaniem preparatów L- karnityny, argininy koenzymu Q.

Zespól CADASIL - mózgowa autosomalna dominująca arteriopatia z zawałami podkorowymi i leukoencefalopatią ( ang. Cerebral Autosomal Dominant Arteriopathy with Subcortical Infarcts and Leukoencephalopathy)

Zespół CADASIL to dziedziczona autosomalnie dominująco choroba związana $\mathrm{z}$ mutacjami zlokalizowanego na chromosomie 19p13.1-13.2 genu syntetyzującego białko receptorowe Nortch 3 znajdującego się na komórkach mięśniówki gładkiej naczyń krwionośnych[10].Szacuje się, że zespół CADASIL występuje z częstością 1: 2500050 000, brak jednak dokładnych danych ze względu na rzadkie występowanie zespołu[11]. Objawy choroby pojawiają się najczęściej w 4. i 5. dekadzie życia ale mogą występować wcześniej. Dzieci powinny być diagnozowane, gdy występuje wywiad rodzinny w kierunku choroby, obecne są objawy niedowładu połowiczego albo przebyte przemijające ataki niedokrwienne- TIA[11]. W mikroskopie elektronowym stwierdza się przy błonie podstawnej ziarnistości osmofilne (ang. Granular Osmophilic Material -GOM,) przy błonie podstawnej. Zmiany patologiczne obecne są przede wszystkim w średniego kalibru tętniczkach istoty białej a także w naczyniach żylnych a w przypadku złogów GOM również w kapilarach. Pierwszymi objawami są zwykle przemijające ataki niedokrwienne, nawracające podkorowe udary (u 40-80\% pacjentów dorosłych) , migrena, często z aurą (u 20-40\% dorosłych),zaburzenia poznawcze, naczyniopochodne otępienie, zaburzenia psychiczne, najczęściej depresja. U 10\% pacjentów stwierdza się padaczkę. Badaniem pozwalającym na przeżyciowe rozpoznanie zespołu jest biopsja skóry oraz ocena w mikroskopie świetlnym i elektronowym zmian w naczyniach krwionośnych. Potwierdzeniem rozpoznania zespołu CADASIL jest wynik badania genetycznego stwierdzający obecność mutacji w genie NOTCH3.

$\mathrm{W}$ rezonansie magnetycznym, w obrazach T2 zależnych obecne są liczne udary lakularne i zmiany istoty białej okołokomorowej szczególnie w płacie skroniowym oraz płatach czołowym ciemieniowym. - zmiany te są postępujące w czasie [11].

\section{Choroba Takayasu / Zapalenie tętnic Takayasu (ang. Takayasu's arteritis)}

Choroba Takayasu jest pierwotnym idiopatycznym przewlekłym zapaleniem aorty i jej dużych odgałęzień z zajęciem lub bez zajęcia tętnic płucnych[12]. Zwana jest też chorobą łuku aorty. Obecnie za podłoże choroby uważa się zaburzenia immunologiczne współistniejące z czynnikami genetycznymi oraz środowiskowymi. Istnieją opisy współistnienia choroby Takayasu z młodzieńczym idiopatycznym zapaleniem stawów, toczniem rumieniowatym układowym, ziarniniakowatością Wegenera, sarkoidozą, chorobą Crohna oraz colitis ulcerosa. Charakteryzuje się ziarniniakowym zapaleniem ściany naczyń tętniczych doprowadzającym do odcinkowego zwężenia bądź zamknięcia światła naczynia. Obserwuje się powstawanie poszerzeń naczyń oraz tętniaków.

Choroba występuje rzadko zarówno w populacji dorosłych, jak i w wieku rozwojowym i związana jest z predyspozycją genetyczną w zakresie układu HLA, szczególnie HLAB5201, HLADR2, chociaż w piśmiennictwie znajdują się opisy dotyczące różnych podtypów. Najczęściej obserwowana jest w Afryce Japonia, Indiach są opisy choroby pochodzące Tajlandii, Singapuru i zachodniej Europy, zatem dotyczy różnych ras głownie młodych kobiet. Badania prowadzone u dzieci wskazują również na przewagę występowania choroby u dziewczynek. Początek choroby najczęściej przypada na 2. i 3. dekadę życia, ale choroba jest rozpoznawana również u małych dzieci[13]. Rozpoznanie choroby w pierwszej fazie jest bardzo trudne, gdyż początkowo objawy są mało charakterystyczne. Objawy w początkowej, często długo trwającej fazie, mogą być bardzo różne i nie zawsze obserwowane u dzieci. Najczęściej występuje gorączka, nocne poty, osłabienie, utarta masy ciała, zmiany skórne, bóle stawowe lub mięśniowe, mogą występować zawroty głowy, zaburzenia widzenia. Zajęcie naczyń ośrodkowego układu nerwowego doprowadza do występowania zespołów TIA, udarów krwotocznych bądź niedokrwiennych[14]. Mogą występować objawy ze strony układu oddechowego , krążenia lub pokarmowego, moczowego w związku z zajęciem naczyń tych narządów. U dzieci, co wynika z piśmiennictwa, najczęstszymi wczesnymi objawami są bóle brzucha, bóle głowy, gorączka, utrata masy ciała, chromanie kończyn. W późniejszym okresie stwierdza się nadciśnienie tętnicze, szmer nad dużymi naczyniami tętniczymi, różnicę wartości ciśnienia tętniczego o ponad $30 \mathrm{~mm} \mathrm{Hg}$ mierzonego na obu kończynach. . Mogą pojawić się charakterystyczne zmiany na dnie oczu (wysięki w postaci ognisk „kłębków waty”, krwawienia do siatkówki a także do ciała szklistego).

Głównym badanie diagnostycznym jest angiografia naczyń w postaci angio -MR lub angio- TK. Na podstawie tego badania rozróżnia się cztery typy choroby:

Typ I - zajęcie łuku aorty i odchodzących od niego naczyń tętniczych.

Typ II - zajęcie aorty piersiowej i brzusznej.

Typ III- zajęcie aorty nad i pod przeponą.

Typ IV-zmiany ogólne z zajęciem aorty płucnej [12,13].

W latach 1978-2000 w RedCross War Memorial Hospital obserwowano grupę 26 dzieci w wieku od 6 mc. Do 14 lat ( 15 dziewczynek, 11 chłopców) z chorobą Takayasu. Zmiany typu I stwierdzono u 1 dziecka, u 14 zmiany typu II a u 11 zmiany typu III. Większość pacjentów bo 24 miało nadciśnienie tętnicze [15].

W różnicowaniu choroby należy uwzględnić choroby układowe tkanki łącznej min. postać uogólnioną młodzień- 
czego idiopatycznego zapalenia stawów, gorączkę reumatyczną, guzkowe zapalenie tętnic, chorobę Behçeta a także waskulopatie niezapalne w przebiegu dysplazji włóknisto-mięśniowej, chorobę Rendu-Oslera-Webera, zespół moyamoya czy choroby uwarunkowanych genetycznie, przede wszystkim zespół Ehlersa--Danlosa, nerwiakowłókniakowatość.

\section{Choroba Fabry'ego}

Choroba Febry'ego(ang. Fabry disease, FD) to lizosomalna choroba spichrzeniowa, dziedziczona recesywnie, sprzężoną $\mathrm{z}$ chromosomem $\mathrm{X}$, a spowodowana mutacją w genie GLA ( locus Xq22); efektem tej mutacji jest niedobór $\alpha$ - galaktozydazy A [16].

Odkładanie się glikolipidów w naczyniach krwionośnych układu nerwowego jest przyczyną udarów mózgu ( u ok. $20 \%$ ) i przemijających ataków niedokrwiennych, zwłaszcza u młodych osób. Występowanie powikłań naczyniowo-mózgowych w tym schorzeniu jest wykładnikiem wielu procesów, w tym dysfunkcji oraz aktywacji komórek endotelium, aktywacji kaskady procesów zapalnych prowadzących do nadkrzepliwości oraz powikłań zatorowych na skutek zaburzeń rytmu i rozwoju kardiomiopatii [17]. Zakażenie pacjenta z FD wirusem COVID19 zwiększa ryzyko wystąpienia powikłań naczyniowych, zarówno niedokrwiennych, jak i krwotocznych[18].

Z uwagi na sposób dziedziczenia chorują głównie mężczyźni, natomiast kobiety są nosicielkami wadliwego genu, chociaż znane są przypadki łagodnych zachorowań również u kobiet. Choroba posiada szeroką i różnorodną manifestację, dlatego tez rozpoznanie bywa trudne, a czas pomiędzy pierwszymi objawami schorzenia, a rozpoznaniem- długi. Objawy nefropatii, zwykle jako pierwsze występujące w FD u dzieci, powinny stanowić o poszerzeniu diagnostyki z uwzględnieniem rozpoznania schorzenia zasadniczego.

Objawy FD mogą pojawić się już w dzieciństwie w postaci nawracających bólów brzucha, dłoni i stóp z towarzyszącymi parastezjami, charakterystycznych zmian skórnych o typie angiokeratoma, złej tolerancji na zmiany temperatury, niewydolności nerek oraz niewydolności mięśnia sercowego. W badaniu widoczne charakterystyczne rysy twarzy: grube wargi „kartoflany nos”, duże wargi, zmiany o typie angiokeratoma na skórze. W diagnostyce tej choroby oznacza się stężenie alfa galaktozydazy we krwi.

Obecnie dostępne są w Polsce dwa preparaty które stosuje się w chorobie Fabry’ego : agalzydazę beta oraz agalzydazę alfa. Dane z piśmiennictwa pokazują, że leki zwalniają postęp choroby oraz ograniczają występowanie części objawów.

\section{Choroba Kawasaki}

Choroba Kawasaki( ang. Kawasaki disease, KD), jest ostrym zapaleniem naczyń krwionośnych, przede wszystkim średniego kalibru, a szczególnie - naczyń serca. Po raz pierwszy choroba została opisana w 1967 roku przez japońskiego pediatrę Tomisaku Kawasaki, stąd też pochodzi jej nazwa[19]. Przyczyna i etiopatogeneza choroby nie jest znana, natomiast wystąpienie objawów choroby u pacjenta często poprzedza infekcja dróg oddechowych. Najpewniej u osób o predyspozycji genetycznej dochodzi do nieprawidłowego pobudzenia komórek odpowiedzi immunologicznej na antygeny drobnoustrojów, co prowadzi do wystąpienia nacieku zapalnego ściany naczyń i ich martwicy. Choroba występuje na całym świecie, jednak najczęściej notowana jest w Japonii, gdzie jej częstość występowania wynosi około 240/100000 dzieci poniżej 4 lat [19]. Z kolei w Ameryce Północnej zapadalność na KD wynosi około 17/100000. Najwięcej, bo kolo 85\% przypadków, dotyczy dzieci poniżej 5 lat, ale stwierdza się zachorowanie zarówno u młodszych, jak i u starszych pacjentów; chłopcy chorują 1,5 krotnie częściej niż dziewczynki[20]. Obserwuje się także sezonowość zachorowań; w Polsce zachorowania występują najczęściej w styczniu, najrzadziej w maju. Nawroty u dzieci japońskich występują u około 3\%, natomiast śmiertelność wynosi około 0,17. Najmłodsze dzieci, po przebyciu KD, są szczególnie narażone na wystąpienie powikłania pod postacią tętniaków tętnic wieńcowych.

Początek choroby jest ostry, zaczyna się zwykle wysoką gorączką trwającą przynajmniej $5 \mathrm{dni}$, niereagującą na leki przeciwgorączkowe ani też stosowane antybiotyki. Na podstawie przebiegu klinicznego wyróżnia się trzy fazy choroby: ostrą, podostrą i fazę zdrowienia [20].

W fazie ostrej (10-14 dni) stwierdza się znaczne przekrwienie spojówek ( charakterystyczny „, objaw czerwonych oczu'), żywoczerwoną błonę śluzową gardła oraz jamy ustnej, malinowy język, suchą, spękaną i krwawiącą czerwień wargową; wysypka może przypominać odrę lub szkarlatynę. Na części grzbietowej rąk i stóp pojawia się twardy obrzęk, skóra jest napięta i bolesna. W tym okresie choroby dochodzi do zapalenia mięśnia sercowego i często do niewydolności krążenia, jak również mogą wystąpić objawy zapalenia opon mózgowo- rdzeniowych, objawy ze strony przewodu pokarmowego, bóle brzucha, wymioty, nudności, biegunka, powiększenie wątroby, zmiany w nerkach, powiększenie węzłów chłonnych a przede wszystkim zapalenie wielu stawów.

W podostrej fazie choroby zwykle trwającej 12-25 dni obserwuje się masywne, płatowe złuszczanie skóry dłoni i stóp. W tej fazie (u 25-30\% chorych) mogą rozwijać się tętniaki, a także powstawać zakrzepy w naczyniach wieńcowych.

W fazie zdrowienia (28-30 dni) dzieci czują się zwykle dobrze, jednak w tym okresie występować zawały mięśnia sercowego.

W literaturze obecne są opisy udarów niedokrwiennych mózgu u pacjentów z rozpoznaną chorobą Kawasaki, zarówno u dzieci, jak i u osób starszych. Do roku 2019 opisano łącznie 16 przypadków dzieci z udarem mózgu w przebiegu choroby Kawasaki [21].

Badania autorów koreańskich przeprowadzone przy pomocy SPECT( ang. single- photon emission computer tomography) wykazały, że zmiany poniedokrwienne w obrębie ośrodkowego układu nerwowego u dzieci z chorobą Kawasaki są znacznie częstsze, niż dotychczas przypuszczano; w większości mają one przebieg bezobjawowy[22]. Zmia- 
ny zapalne naczyń mózgowych pojawiające się w przebiegu KD mogą wystąpić w okresie od 3 dnia do 4 miesięcy od rozpoznania choroby zasadniczej.

Odległym zwykle powikłaniem choroby jest wczesny rozwój miażdżycy. Wieloletnie obserwacje pacjentów po przebytej chorobie Kawasaki wykazały, iż grubość intima media ( ang. carotid intima media thickness, cIMT) u dzieci bez tętniaków naczyń wieńcowych miała początkowo tendencję do wzrastania , ale ostatecznie ulegała normalizacji w stosunku do wartości obserwowanych u pacjentów z grupy kontrolnej. Natomiast u dzieci $\mathrm{z}$ dużymi tętniakami tętnic wieńcowych tendencja do narastania grubości cIMT utrzymywała się. Obserwacje te wskazują na konieczność stałego monitorowania dzieci po przebytej chorobie Kawasaki w aspekcie ryzyka schorzeń sercowo-naczyniowych [23 ].

\section{Dysplazja włóknisto- mięśniowa}

Dysplazja włóknisto-mięśniowa to choroba o niezapalnej etiologii, która u dzieci, w odróżnieniu od pacjentów dorosłych, nie ma predylekcji do płci. Częsta manifestacja u pacjentów pediatrycznych to nadciśnienie tętnicze, jednak z uwagi na rzadkie występowanie dysplazji u dzieci rozpoznanie bywa stawiane późno, kiedy nadciśnienie jest utrwalone i poddaje się leczeniu[24]. Upacjentów dorosłych choroba występuje zwykle u kobiet. Patologia dotyka zwykle ściany naczyń, głównie nerkowych i domózgowych, obejmuje elementy elastyczne, mięśniowe i włókniste, które dotyczą zwykle naczyń drobnego i średniego kalibru. Cechą charakterystyczną są ogniskowe poszerzenia i zwężenia światła dużych naczyń, co opisywane jest jako „sznur korali”. Zmiany w budowie ściany naczynia prowadzą do występowania udarów niedokrwiennych bądź krwotoku podpajęczynówkowego w wyniku pękniętego tętniaka. Rozpoznanie stawiane jest na podstawie angiografii naczyń domózgowych. W piśmiennictwie dostępne są nieliczne, kazuistyczne opisy dzieci z udarem mózgu w przebiegu dysplazji włóknisto mięśniowej, w tym także 12-letniej dziewczynki leczonej trombolizą dożylną z dobrym skutkiem [25].

\section{PIŚMIENNICTWO}

[1] Felling R.J., Sun L.R., Maxwell E.C., et al.: Pediatric arterial ischemic stroke: Epidemiology, risk factors, and management. Blood Cells Mol Dis, 2017; 67: 23-33.

[2] Balabanov R., Dore-Duffy R.: Vasculitides of the nervous system [w:] Antel A., Hartung H., VincentA. (red.) Clinical neuroimmunology. Oxford University Press, Oxford, 2005; 381-399.

[3] Parapia L.A., Jackson C.: Ehlers- Danlos syndrome- a historical review. BJHaem, 2008; 1: 32-35.

[4] Castori M., Comerota F., CellettiC., et al.: Natural history and manifestations of the hypermobility type Ehlers- Danlos syndrome: a pilot study on patients. Am J Med Genet, 2010; 152A: 556-564.

[5] Castori M., Voermans N.C.: Neurological manifestations of Ehlers- Danlos syndrome: A review. Iran J Neurol,2014; 13: 190.

[6] Tinkle B., Castori A., Berglund B., et al.: Hypermobile Ehlers-Danlos Syndrome (a.k.a. Ehlers-Danlos Syndrome Type III and Ehlers-Danlos Syndrome Hypermobility type): Clinical Description and natural history. Am J Med Genet, 2017; 175C: 48-69.

[7] Surtees R., Kirkham F.J.:Inborn metabolic disease and acute focal neurology. [w:] Stroke and cerebrovascular disease in childhood. V. Ganesan, F. Kirkham [red.]. Mac Keith Press, 2011.

[8] Abu-Amero K.K., Al- Dhataan H., Hellani A., et al.: Patient with typical clinical features of mitochondrial encephalopathy, lactic acidosis and stroke-like episodes (MELAS) but without an obvious genetic cause: a case report. J Med Case Report, 2009; 3: 77.

[9] Modrzejewska M.: Zmiany oczne w przebiegu zespołu MELAS. Klinika Oczna, 2016: 118.

[10]Kirkham F.J., Dlamini N.: Genetically determined vasculopathies and stroke syndroms without neurocutaneous sigmate. [w:] Stroke and cerebrovascular disease in childhood. V. Ganesan, F. Kirkham [red.]. Mac Keith Press, 2011.

[11] Hartley J. ,Westmacott R., Decker J., et al.: Childhood -onset CADASIL: clinical imaging and neurocognitive features. J Child Neurol, 2010; 25: 623-627.

[12] Kirkham F.J.: Inflammatory vasculopathies. [w:] Stroke and cerebrovascular disease in childhood. V. Ganesan, F. Kirkham [red.]. Mac Keith Press, 2011.

[13] Kim H.J., Suh D.C., Kim J.K., et al.: Correlation of neurological manifestations of Takayasu's arteritis with cerebral angiographic findings. Clin Imaging,2005; 29: 79-85.

[14] Johnston S.L., Lock R.J., Gompels M.M.: Takayasu arteritis: a review. J Clin Pathol, 2002; 55: 481-486.

[15] McCulloch M., Andronikou S., Goddard S., et.al.: Angiographic features of 26 children with Takayasu's arteritis. Pediatr Radiol, 2003; 33: 230-235.

[16] Ries M., Gupta S, Moore D.F. ,et al.:Pediatric Fabry disease. Pediatrics, 2005; 115: 344-355.

[17] Kargiotis 0., Psychogios K., Safouris A., et al.: Intravenous Thrombolysis for Acute Ischemic Stroke in Fabry Disease. Neurologist, 2019; 24:146149.

[18] Reisin R.C., Rozenfeld P., Bonardo P. Fabry disease patients have an increased risk of stroke in the COVID-19 ERA. A hypothesis. Med. Hypotheses, 2020; 144: 110228.

[19] Fersirgaton E., Moffett B.S.: Kawasaki disease. A review. J Pediatr. Health Care, 2001; 25: 379-387.

[20] Hedrich Ch., Schnabel A.: Kawasaki disease. Fronti Pediatr, 2018; 6: 1-10.

[21] Sabatier I., Chabrier S., Brun A., et al.: Stroke by carotid artery complete occlusion in Kawasaki disease: Case report and review of literature. Pediatr Neurol, 2013; 49:469-473.

[22] Yeom J.S.,Cho J.Y., Woo H.-O.: Understanding the importance of cerebrovascular involvement in Kawasaki disease. Korean J Pediatr, 2019; 62: 334-339.

[23] Diez S.M., Tacke C.E., de Groot E.et al.: Extracardial Vasculopathy After Kawasaki Disease: A Long Term Follow- up Study. J Am Heart Assoc, 2016; 5: e003414.

[24] Louis R., Levy-Erez D., Cahill A.M. et al.: Imaging studies in pediatric fibromuscular dysplasia(FMD): A single center experience. Pediatr Nefrol, 2018; 3: 1593-1599.

[25] Bolognese M., Griebe M., Foerster A., et al.: Thrombolytic stroke treatment of a 12-year-old girl with intracranial fibromuscular dysplasia. Case Rep Neurol, 2011; 3: 210-213. 